\title{
Nodular lymphocyte-predominant Hodgkin lymphoma characteristics, management of primary and relapsed/refractory disease and outcome analysis: the first comprehensive report from the Middle East
}

Saad Akhtar ${ }^{1 *}$ (D) M. Shahzad Rauf ${ }^{1}$, Yasser Khafaga', Amani Al-Kofide², Tusneem Ahmed M. Elhassan', Mahmoud A. Elshenawy ${ }^{1}$, Juzer Nadri ${ }^{3}$, Ali Hassan Mushtaq ${ }^{3}$, Nasir Bakshi', Mohammed Shamayel ${ }^{4}$, Suleiman Al-Sweedan ${ }^{2}$, Sohail Sarwar ${ }^{1}$ and Irfan Maghfoor ${ }^{1}$

\begin{abstract}
Background: Nodular lymphocyte-predominant Hodgkin lymphoma (NLPHL) is an uncommon variant of Hodgkin lymphoma. There is limited data on treatment, management of refractory and relapsed disease, and long-term outcome. Many registries or country-wide data reports are unable to provide detailed primary and subsequent management. We are reporting our observation on patient's characteristics, management, and outcome.
\end{abstract}

Methods: This single-institution retrospective cohort analysis includes NLPHL patients seen from 1998 to July 2019. We used Fisher's exact test, chi-square, and Kaplan-Meier (KM) method for various analyses.

Results: Two hundred patients were identified, (6.34\% of all the HL). Male:female was 3:1. The median age at diagnosis was 22 years (4-79 years). Stage I-II in 145 (72.5\%) cases. One hundred patients (50\%) received chemotherapy, 68 (34\%) chemotherapy + radiation therapy (RT); 87\% of all chemotherapy was ABVD (adriamycin, bleomycin, vinblastine, dacarbazine). Thirteen patients (6.5\%) received RT alone and 16 (8\%) had surgery alone. Complete response in $82 \%$, partial response in $5.5 \%$ and progressive disease in $10.5 \%$. The median follow is 60 months (5-246). Median 5 and 10 years overall survival (OS) is 94.8 and $92.4 \%$ (stages I-II, 97.7 and $97.7 \%$, stage III-IV, 94.8 and 92.4\%). Median event-free survival (EFS) is 62.3 and 54\% respectively (stage I-II, 72 and 64\%, stage III-IV, 36.4 and $18.2 \%)$. Stage I-II VS III-IV OS $(p=<0.001)$ and EFS $(p=<0.001)$ were significant. For stage I-II, 5 year EFS of chemotherapy + RT (83.3\%) was superior to chemotherapy alone $(60 \%, p=0.008)$. Five year EFS for early favorable (80\%), early unfavorable (60\%), and advanced (36.4\%) was significant $(p=<0.001)$. Eleven patients (5.5\%) had highgrade transformation. Twenty-nine patients underwent HDC auto-SCT, all are alive (28 in remission). 25\% of patients had pathologically proved nodal hyperplasia at some point in time.

(Continued on next page)

\footnotetext{
* Correspondence: sakhtar@kfshrc.edu.sa

'Oncology Center, King Faisal Specialist Hospital and Research Center, Riyadh, Kingdom of Saudi Arabia

Full list of author information is available at the end of the article
}

(c) The Author(s). 2021 Open Access This article is licensed under a Creative Commons Attribution 4.0 International License, which permits use, sharing, adaptation, distribution and reproduction in any medium or format, as long as you give appropriate credit to the original author(s) and the source, provide a link to the Creative Commons licence, and indicate if changes were made. The images or other third party material in this article are included in the article's Creative Commons licence, unless indicated otherwise in a credit line to the material. If material is not included in the article's Creative Commons licence and your intended use is not permitted by statutory regulation or exceeds the permitted use, you will need to obtain permission directly from the copyright holder. To view a copy of this licence, visit http://creativecommons.org/licenses/by/4.0/ The Creative Commons Public Domain Dedication waiver (http://creativecommons.org/publicdomain/zero/1.0/) applies to the data made available in this article, unless otherwise stated in a credit line to the data. 
(Continued from previous page)

Conclusion: OS of NLPHL is excellent and independent of treatment type. EFS is better for chemotherapy + RT than chemotherapy alone. Stem cell transplant in refractory / multiple relapses resulted in excellent disease control. There is a need to identify optimal treatment strategies accordingly to the risk stratification.

\section{Background}

Nodular lymphocyte-predominant Hodgkin lymphoma (NLPHL) is a relatively uncommon subtype of Hodgkin lymphoma (HL) that accounts for about $5-6 \%$ of all $\mathrm{HL}$ cases. World Health Organization classification of lymphoid neoplasm recognizes NLPHL as a separate entity with unique morphologic, immunohistochemical, and clinicopathological characteristics [1]. The presence of atypical "lymphocyte-predominant cells", (LP cells) or popcorn cells is characteristic. These cells express CD20 positivity and CD 15 and CD 30 negativity in a background of non-malignant and reactive nodular small mature B-lymphocytes which is a characteristic histological feature of NLPHL [2]. Although long-term survival is better than classical HL, frequent relapses and progression/transformation to aggressive non-Hodgkin lymphoma (NHL)/ diffuse large B cell lymphoma (DLBCL) is reported [3-8]. There is no randomized trial addressing the treatment strategies specifically designed for NLPHL and most of the data and information are extracted from either small series or subset analyses of larger HL registries. Data are even limited for relapsed and refractory NLPHL. There are few reports on high dose chemotherapy and auto-SCT (HDC auto-SCT) in relapsed and refractory setting [9-12]. Due to the expression of CD20 positive cells, rituximab has been reported as an effective treatment in NLPHL [13, 14]. Studies are reporting a higher incidence of both solid and hematological malignancies in the families of these patients. We are reporting the first large data from the Middle East on patient characteristics, treatment, and outcome in a relatively uniformly treated group of younger patients with long follow-up. We also discuss the finding of reactive lymphadenopathy in these patients during their disease, highgrade transformation (HGT), and its management and outcome. In this report, we will also update the outcome of our previously reported patients who underwent HDC auto-SCT.

\section{Methods}

\section{Study design and ethical permission}

This is a single institution retrospective cohort analysis using Institutional Research Advisory Counsel and Ethics Committee approved adults (age $>14$ years) and pediatrics (age $<14$ years) lymphoma databases. This waiver of signed consent was approved by the Research Advisory Council for participation in the database collection study and subsequent publications as per. Verbal consent was obtained and documented in the paper/ electronic chart. All patients and/or their guardians provided informed consent for all treatments and procedures as per institutional requirements.

\section{Patients and definitions}

All NLPHL adult and pediatric patients seen in the hospital from 1998 to July 2019 were identified using Adult Medical Oncology and Pediatrics Hematology / Oncology lymphoma databases. Patients with a concomitant diagnosis of NLPHL and transformed DLBCL were not eligible. Paper and electronic charts were reviewed to collect patient's characteristics, treatment details, follow up and outcome data. Ann Arbor / Cotswolds modification staging system was used for staging. The refractory disease was defined as partial response (PR), no response (NR)/ stable disease (SD), or progressive disease (PD) after planned chemotherapy with or without radiation therapy (RT) or relapsing within 3 months from the end of the planned treatment after achieving a complete remission $(\mathrm{CR})$ or $\mathrm{CR}$ unconfirmed $(\mathrm{CRu})$. RT details were collected by a senior RT physician (YK) and included RT site, total dose delivered, dose per fraction, field information i.e. extended field RT (EFRT), involved field RT (IFRT), and involved site RT (ISRT). Information on RT treatment technique i.e. conventional 2D, 3D-conformal, or volumetric modulated arc therapy (VMAT) intensitymodulated RT (IMRT), and RapidArc were also collected.

\section{Imaging studies and response assessment}

All patients had staging CT scans of chest, abdomen, and pelvis with and without contrast and CT scan of the head, neck, and other areas as needed. Many patients had 18F-fluorodeoxyglucose positron emission tomography (FDG-PET/CT) scan at staging and response assessment as it became available. CR, PR, NR/SD, PD were all defined according to the International Working Group [15] response assessment/criteria for CT scan. Mediastinal blood pool structure uptake activity and subsequently Deauville five-point criteria was used for FDG-PET/CT scan interpretation [16].

\section{Pathology review}

Expert hematopathologist/s reviewed the pathology specimens. All these reports were re-reviewed by two hematopathologists (NB, MS) and specimens (as needed) were reevaluated until complete agreement achieved in 
all cases as needed. The World Health Organization (WHO) 2008 criterion for diagnosing lymphoma was used [17]. All available pathology reports were reviewed to identify reactive lymphadenopathy.

\section{Statistical analysis}

Patient characteristics were summarized using frequencies and medians with ranges and compared using Fisher's exact test and Mann-Whitney $U$ test for categorical and continuous variables respectively. Survival probabilities were calculated using Kaplan-Meier (KM) methods with variance estimated using the Greenwood formula. Overall survival (OS) was defined as time to death from any cause and event-free survival (EFS) was defined as time to persistent, progressive, relapsed disease or death. Patients who are alive and disease-free at the time of the last follow-up are censored. Cox proportional hazard model was utilized to compare the risk between study groups. All variables were tested for affirmation of proportionality assumption and no variable had violated the assumption. All statistical analysis was carried out using SPSS version 23 and $P$-value $<0.05$ was considered significant. However, for subgroup analysis, a $p$-value less than 0.01 was considered significant to adjust for multiple comparisons. We also risk-stratified our patients according to the German Hodgkin Study Group (GHSG) risk models; early favorable, early unfavorable, and advanced [18]. "KM survival analysis was also performed for different prognostic factors and clinical and laboratory parameters. Factors with a p-value $<0.1$ were tested for multivariate analysis; we used Forward Method utilizing the Likelihood Ration (LR) with the entry criteria 0.1 and 0.05 for the removal.

\section{Results}

\section{Patients characteristics}

Between 1998 to 7-2019, we identified 200 patients with NLPHL who met the eligibility criteria. Male:female is 3 : 1 . The median age at diagnosis is 22 years ( $4-79$ years) with $98(49 \%)$ patients $<21$ years at diagnosis. The median age was similar for both females (22.4 years) and males ( 21 years). Our hospital tumor registry is updated till 2014, from which we identified a total of 2020 patients of HL from 1998 to 2014, of those, 128 were NLPHL, representing $6.34 \%$ of all the HL during this time frame. There is likely to be a higher percentage of NLPHL from 2015 to 2019 as 72 cases have already been identified. Further detailed analysis can only be performed once 2015-2019 data is available from the hospital tumor registry. Patient characteristics at diagnosis, their treatment, and the outcome are shown in Tables 1 and 2. All patients had conventional CT scanning for staging. During 2010-2019, staging with FDG-PET/CT scan became increasingly common. From 1998 to 2009,
Table 1 Patient's characteristics at initial presentation

\begin{tabular}{|c|c|c|}
\hline Variable & Total patients & Percentage \\
\hline Total patients & 200 & 100 \\
\hline Male & 151 & 75.5 \\
\hline Female & 49 & 24.5 \\
\hline Median age at diagnosis & 200 & 22 yrs. (4-79 years) \\
\hline$\leq 14$ years & 40 & 20 \\
\hline$>14-21$ & 57 & 28.5 \\
\hline$>21-30$ & 39 & 19.5 \\
\hline$>30-50$ & 50 & 25 \\
\hline$>50$ & 14 & 7 \\
\hline Stage I & 75 & 37.5 \\
\hline Stage II & 70 & 35 \\
\hline Stage III & 41 & 20.5 \\
\hline Stage IV & 14 & 7 \\
\hline Bulky disease involvement & 19 & 9.5 \\
\hline Spleen involvement & 22 & 11 \\
\hline Extranodal involvement & 25 & 12.5 \\
\hline Bone marrow involvement & 5 & 2.5 \\
\hline B symptoms present & 14 & 7 \\
\hline Early favorable ${ }^{a}$ & 96 & 48 \\
\hline Early unfavorable $\mathrm{e}^{\mathrm{a}}$ & 14 & 7 \\
\hline Advanced $^{a}$ & 55 & 27.5 \\
\hline Risk group unknown ${ }^{a}$ & 35 & 17.5 \\
\hline $\mathrm{LDH}>$ normal & 40 & 20 \\
\hline LDH missing & 50 & 25 \\
\hline Performance status $\geq 2$ & 6 & 3 \\
\hline Performance status unknown & 44 & 22 \\
\hline
\end{tabular}

${ }^{\mathrm{a}}$ As per German Hodgkin Study Group

27/85 patients (31.8\%) had staging FDG-PET/CT scan as compared to $99 / 115$ patients (86\%) from 2010 to 2019 $(\mathrm{p}=<0.001)$. Despite this higher use of FDG-PET/CT scan, there was no change in the incidence of stage I-II (71.2 and $73 \%, p=0.87$ ) during these two periods respectively. Early stages represented the majority of the patient population; stage I-II in $145(72.5 \%)$ cases. Only $3 / 145$ patients $(2 \%)$ with stage I-II had B symptoms as compared to $11 / 55(20 \%)$ with stages III-IV $(\mathrm{p}=<0.001)$. The bulky disease was present in $8 / 145$ patients $(5.5 \%)$ with stage I-II as compared to $11 / 55(20.4 \%)$ with stages III-IV $(p=0.012)$. Laterality information for stage I-II was also available for 141/145 patients; 39 (28\%) rightsided, 53 (37.6\%) left-sided and bilateral in $48(34 \%)$ patients, $p$-value not significant.

\section{Treatment}

Details are shown in Table 2. One hundred sixty-eight patients $(84 \%)$ received chemotherapy or chemotherapy 
Table 2 Treatment and survival outcome

\begin{tabular}{|c|c|c|}
\hline Variable & Total patients & Percentage \\
\hline \multicolumn{3}{|l|}{ Initial treatment } \\
\hline Chemotherapy & 100 & 50 \\
\hline Radiotherapy $^{\mathrm{a}}$ & 13 & 6.5 \\
\hline Surgery alone & 16 & 8 \\
\hline Chemotherapy + Radiotherapy & 68 & 34 \\
\hline Rituximab alone & 2 & 1 \\
\hline Refused / No show & 1 & 0.5 \\
\hline \multicolumn{3}{|l|}{ Type of chemotherapy } \\
\hline$A B V D^{b}$ & 147 & 73.5 \\
\hline ABVD/ABV with COPP like & 3 & 1.5 \\
\hline COPpb & 5 & 2.5 \\
\hline $\mathrm{R}-\mathrm{CHOP}$ & 11 & 5.5 \\
\hline Others $^{d}$ & 6 & 3 \\
\hline \multicolumn{3}{|l|}{ Number of initial chemo cycle } \\
\hline 2 cycles $^{a}$ & 31 & 15.5 \\
\hline 3 cycles & 11 & 5.5 \\
\hline 4 cycles & 64 & 32 \\
\hline 6 cycles $^{a}$ & 53 & 26.5 \\
\hline 8 cycles & 11 & 5.5 \\
\hline \multicolumn{3}{|l|}{ Response after initial treatment } \\
\hline$C R$ & 164 & 82 \\
\hline PR & 11 & 5.5 \\
\hline$P D^{b}$ & 21 & 11.5 \\
\hline On treatment & 1 & 0.5 \\
\hline \multicolumn{3}{|l|}{ Tissue confirmation at $R x$ failure } \\
\hline Type of first event & 200 & 100 \\
\hline No event & 124 & 62 \\
\hline Persistent disease & 12 & 6 \\
\hline Progressive disease & 21 & 10.5 \\
\hline Relapsed disease & 36 & 18 \\
\hline Treatment related mortality & 1 & 0.5 \\
\hline Death other causes & 1 & 0.5 \\
\hline Unknown & 5 & 2.5 \\
\hline \multicolumn{3}{|l|}{ Disease status at last visit } \\
\hline Alive in remission & 176 & 88 \\
\hline Alive with disease & 4 & 2 \\
\hline Alive unknown status & 1 & 0.5 \\
\hline Lost to follow up & 6 & 3 \\
\hline On treatment & 2 & 1 \\
\hline Died of disease & 8 & 4 \\
\hline Died of other cause ${ }^{c}$ & 3 & 1.5 \\
\hline High grade transformation & 11 & 5.5 \\
\hline HDC auto-SCT & 29 & 14.5 \\
\hline
\end{tabular}

Abbreviations: ABVD Adriamycin, bleomycin, vinblastin and dacarbazine, COPP/MOPP Cyclophosphamide / mechlorethamine, vincristine, procarbazine, prednisone, $P R$ partial response

${ }^{a}$ Rituximab $\times 4$ before /or after radiotherapy in 2 patient, ${ }^{b}$ Rituximab + ABVD in 9, Rituximab + COPP in $3,{ }^{c}$ Rituximab + CVP in $2,{ }^{d}$ Rituximab alone (3), rituximab + gemcitabine (1), dexamethasone, Ara-C, cisplatin (1), unknown at other institution (1). ${ }^{a} 1$ cycle in 2,5 cycles in $4,{ }^{b} 2$ patients with no response (NR) or stable disease (SD) in this group, progressive disease (PD), complete remission (CR), complete remission unconfirmed (CRu), ${ }^{c}$ treatment related mortality in 2 (both with lung toxicity after R-ABVD, both in CR ( 1 for relapsed disease after radiation therapy). 1 patient with sickle cell related sever cardiomyopathy, died in CR 
$+\mathrm{RT}$ as the first line. ABVD (adriamycin, bleomycin, vinblastine, and dacarbazine) was the most common regimen in $146(73 \%)$ of 200 patients (87\% of all chemotherapy). Another 22 (11\%) had other combinations, including 12 adriamycin-based regimens. 81 (40.5\%) patients received RT, 68 (34\%) with chemotherapy and $13(6.5 \%)$ as RT alone.

Treatment of stages I-II patient was chemotherapy alone in 53 (36.5\%), RT alone in 13 (9\%) (2 patients also received rituximab), chemotherapy + RT in 62 (42.7\%), surgery alone in $16(11 \%)$ followed by observation and rituximab alone in $2(1 \%)$ patients. Treatment of stages III-IV patients was chemotherapy alone in 47 (85.5\%), chemotherapy + RT in $6(11 \%)$, and unknown in 1.

Rituximab was not commonly used in the first-line treatment of NLPHL up until 2016. Rituximab was used in 28 (14\%) patients; from 2005 to 2015 , only 6/112 (5.4\%) patients received rituximab as compared to $21 / 55$ (38.2\%) from 2016 to July 2019. Rituximab was used alone in 2 , with radiation in 2 , with chemotherapy and RT in 3, and with chemotherapy in 21 patients. Rituximab was combined with CHOP (cyclophosphamide, adriamycin, vincristine, prednisone) (R-CHOP) and ABVD in 9 patients each, with CVP (cyclophosphamide, adriamycin, vincristine) in 2 and with COPP (cyclophosphamide, vincristine, procarbazine, prednisone) in 3. In these patients, the stages were I-II in 12 and III-IV in 16. The Median follow-up of these patients is only 24 months. KM estimates of 24 months EFS is $75.3 \%$ (rituximab group) vs $74.5 \%$ in non-rituximab group $(p=0.7)$. Cox Regression for no-rituximab use was not inferior, $(\mathrm{HR}=1.2,95 \% \mathrm{CI}=0.5-2.8, p=0.7)$. For stage III-IV alone, 16/55 (30\%) received rituximab in the first line, 24 month KM EFS estimate is $66.5 \%$ (rituximab group) vs $55 \%$ (no rituximab group) ( $p=0.42$ ), median EFS was 30 months in each group. The numbers and follow-up are too small for any meaningful subgroup analysis and conclusion.

Radiation therapy

$81 / 200$ patients received RT during their initial treatment (one patient who refused radiation after 2 fractions have been excluded from all the analysis). RT was given both to males (44\%) and females (31\%), and this was not significant $(p=0.32)$. Almost $50 \%$ of patients with stages I (41/76 (53\%)) and II (34/69 (49\%)) received radiation. Another $6 / 41$ (14.6\%) stage III also received RT. The reason for RT was consolidation (already in CR) in 42 (52\%), to eradicate residual disease after chemotherapy in $20(25 \%)$, as a primary/first-line treatment in $13(16 \%)$ and in 6 (7\%), disease status after ABVD chemotherapy / before RT was not checked. Dose of radiation was 15 to 41.4 Gy; 15 to 25.5 in 25 (31\%) and 30 to 41.4 in 56 (69\%). There was no difference in the outcome between the two dose groups $(p=0.6)$. Only 2 patients (before
2005) received $>36$ Gy. Patients who achieved CR on chemotherapy usually received a lower RT dose around 30.6 Gy (38/43). The field of RT was IFRT in 66 (81.5\%), ISRT in $14(17 \%)$, and extended field RT in 1 patient. There was no difference in the outcome between the two RT field groups $(p=0.5)$, although, numbers are too small for any analysis. Over the years, the RT treatment technique has evolved. It was conventional $2 \mathrm{D}$ in 11 (13\%) patients, 3D-conformal in $42(51 \%)$ patients and VMAT/IMRT in 29 (36\%). There was a significant difference in the outcome of these patients due to the reason of RT.

5-year KM EFS for RT as consolidation was $97 \%$ vs as a primary/first-line treatment $(63 \%, \mathrm{HR}=7,95 \% \mathrm{CI}=$ 1.3-36, $p=0.02$ ) compared to RT as consolidation. 5year KM EFS for eradicating residual disease after chemotherapy was $36 \%, \mathrm{HR}=19,95 \% \mathrm{CI}=4.7-80$ ) as compared to RT, $p<0.001$.

\section{Response to treatment and survival analysis}

The Median follow-up of all the alive patients is 60 months ( 1 to 246 months). Twenty-five alive patients (5 lost to follow-up) have less than 12 months follow-up. Overall response was CR in 164 (82\%), PR in 11 (5.5\%), PD in 21 (10.5\%) cases (including 2 patients with no response) and unknown in 3 (1.5\%). Median 5 and 10 years OS for the entire group is 94.8 and $92.4 \%$ respectively. The Median 5 and 10 year EFS for the entire group is 62.3 and $54 \%$. As the treatment modalities and expected outcome are different, stages I-II and III-IV are analyzed separately for the types of treatment and outcome. These survival analyses are shown in Figs. 1, 2, and 3.

\section{Stage I-II}

For stages I-II (145 patients), response to the treatment was CR in 129 (89\%), PR in 5 (3.4\%), PD in $9(6.2 \%)$, and unknown/on treatment in $2(1.4 \%)$. The response was also separately evaluated for all treatment groups. For chemotherapy (54 patients ( 2 patients with rituximab alone included in chemo group)), it was 77.8, 7.4, 11.1, and $3.8 \%$ respectively. For RT (13 patients), it was 100\% $\mathrm{CR}$, for chemotherapy + RT (62 patients), it was 93.5, 1.6, 4.8 and $0 \%$ respectively. For surgical excision and observation, it was $100 \%$ CR. For stage I-II, for various treatment modalities, only 5 year EFS of chemotherapy + RT (83.3\%) was superior to chemotherapy alone (60\%) $(p=0.008)$. For all other groups, the outcome was not statistically different. Cox regression also showed that chemotherapy alone was inferior to chemotherapy $+\mathrm{RT}$ $(\mathrm{HR}=3, \mathrm{CI}=1.7-5.2, p=<0.001)$. However, $\mathrm{RT}$ alone and surgery alone were not statistically inferior to chemotherapy + RT $(\mathrm{HR}=1.41, \mathrm{CI}=0.14-4.8, p=0.58)$ and $(\mathrm{HR}=1.23, \mathrm{CI}=0.36-4.2, p=0.74)$ respectively. 

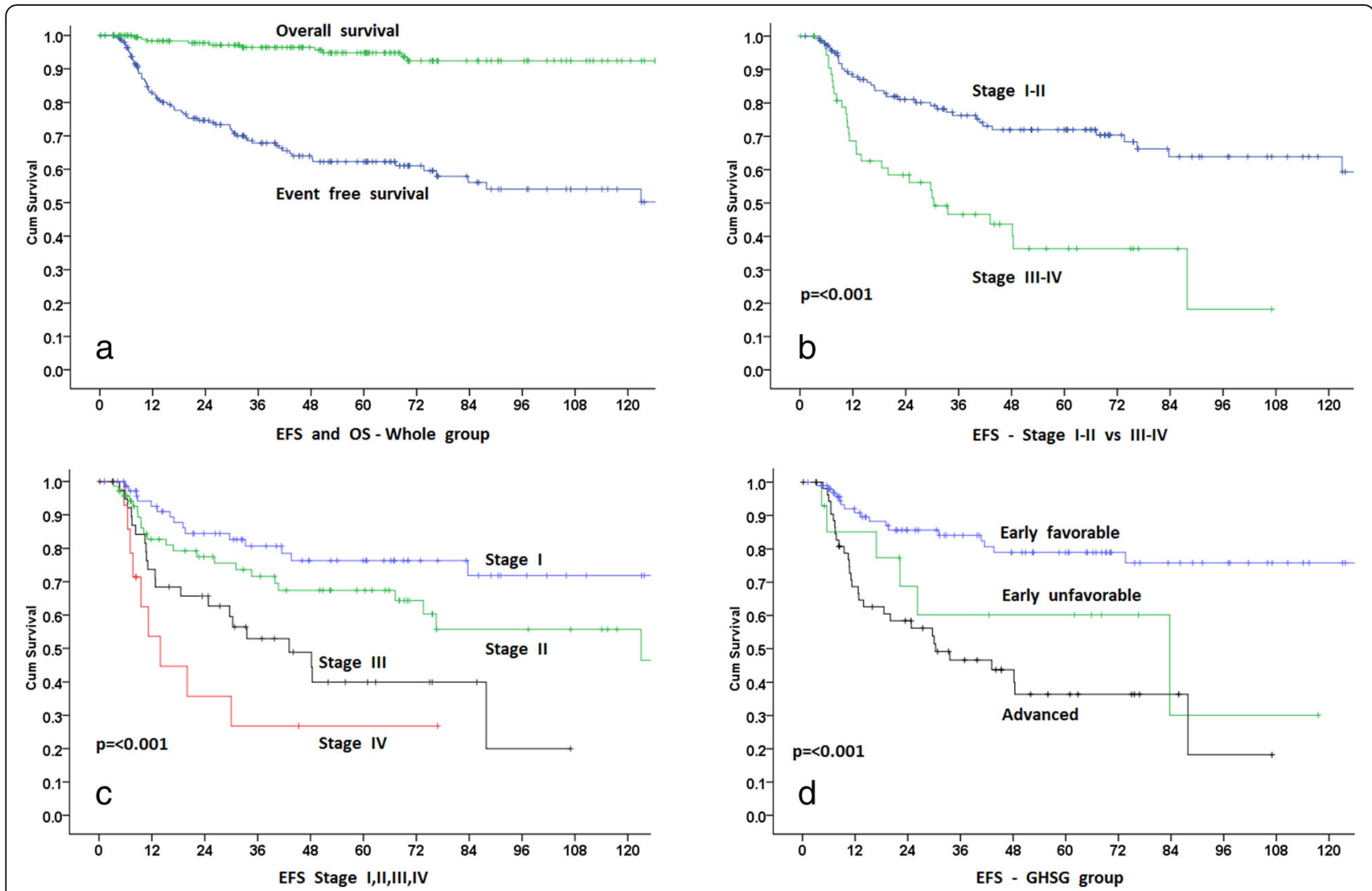

Fig. 1 a, overall and event free survival of entire group. b, event free survival with stage I-II and stage III-IV. $\mathbf{c}$, event free survival with stage I, II, III and IV. d, event free survival according to the German Hodgkin Study Group risk models; early favorable, early unfavorable and advanced

Median 5 and 10 years OS for stages I-II is $97.7 \%$ for both 5 and 10 years. A total of three stage I-II patients have died, one due to chemotherapy-related lung toxicity. KM estimates of 5 and 10 years EFS were 72 and $64 \%$ (stage I, 76.3 and $72 \%$, stage II, 67.4 and $55.7 \%$ respectively). The Median KM estimate of EFS was 146.5 months (stage I, not reached, stage II, 123 months).

We also checked if there is a difference in the EFS based on CT scan staging (53/145 patients) vs FDGPET/CT scan staging (92/145). Median KM estimates of EFS were 150 months (5 and 10 years EFS was 71 and $67 \%)$ for CT scan staging. Median KM estimates of EFS were 146.5 months (5 and 10 years EFS was 74 and 63\%) for FDG-PET/CT scan staging, $(p=0.8)$ and showed that there was no EFS difference regarding staging methodology over time.

\section{Stage III-IV}

CR was observed in 35 (64.8\%), PR in 6 (11\%), PD in 12 $(22.2 \%)$ and unknown in $1(2 \%)$. For chemotherapy alone (48 patients), it was $62.5 \%, 12.5,22$ and $2 \%$ respectively. For chemotherapy + RT (6 patients), it was 83.3, 0, 16.7 and $0 \%$ respectively. Median 5 and 10 years OS for stages III-IV was 87.6 and $79.5 \%$. KM estimates of 5 and
9 years EFS were 36.4 and $18.2 \%$ (stage III, 40 and $20 \%$ and stage IV $26.8 \%$ and not available/short follow-up respectively). The median KM estimate of EFS was 30.4 months (stage III, 43 months, stage IV, 14 months). Cox regression was not performed due to small numbers in the chemotherapy + RT group. The difference in OS between stages I-II vs III-IV OS $(p=0.001)$ and EFS stages I-II vs III-IV EFS ( $p=<0.001)$ was significant. EFS on CT scan staged patients (21/55 patients) vs FDG-PET/ CT scan staged patients (34/55) was also checked. Median KM estimates of EFS were 30 months (5 years EFS was $45 \%$ ) for CT scan staging. Median KM estimates of EFS were 30.4.5 months (5 years EFS was 25\%) for FDGPET/CT scan staging, $(p=0.57)$.

\section{GHSG risk models and outcome}

According to GHSG risk stratification model, 34 patients $(34 / 145$ stage I-II $(18 / 76$ (23.7\%) stage I) and (16/69 (23.2\%) stage II)) had missing information; mainly ESR, and these cases were unclassifiable to early favorable or early unfavorable. Except for 1 stage I patient, 13 out of 14 early unfavorable patients had stage II. Progressive decline in the median EFS for early favorable (not reached), early unfavorable (83.7 months), and advanced 


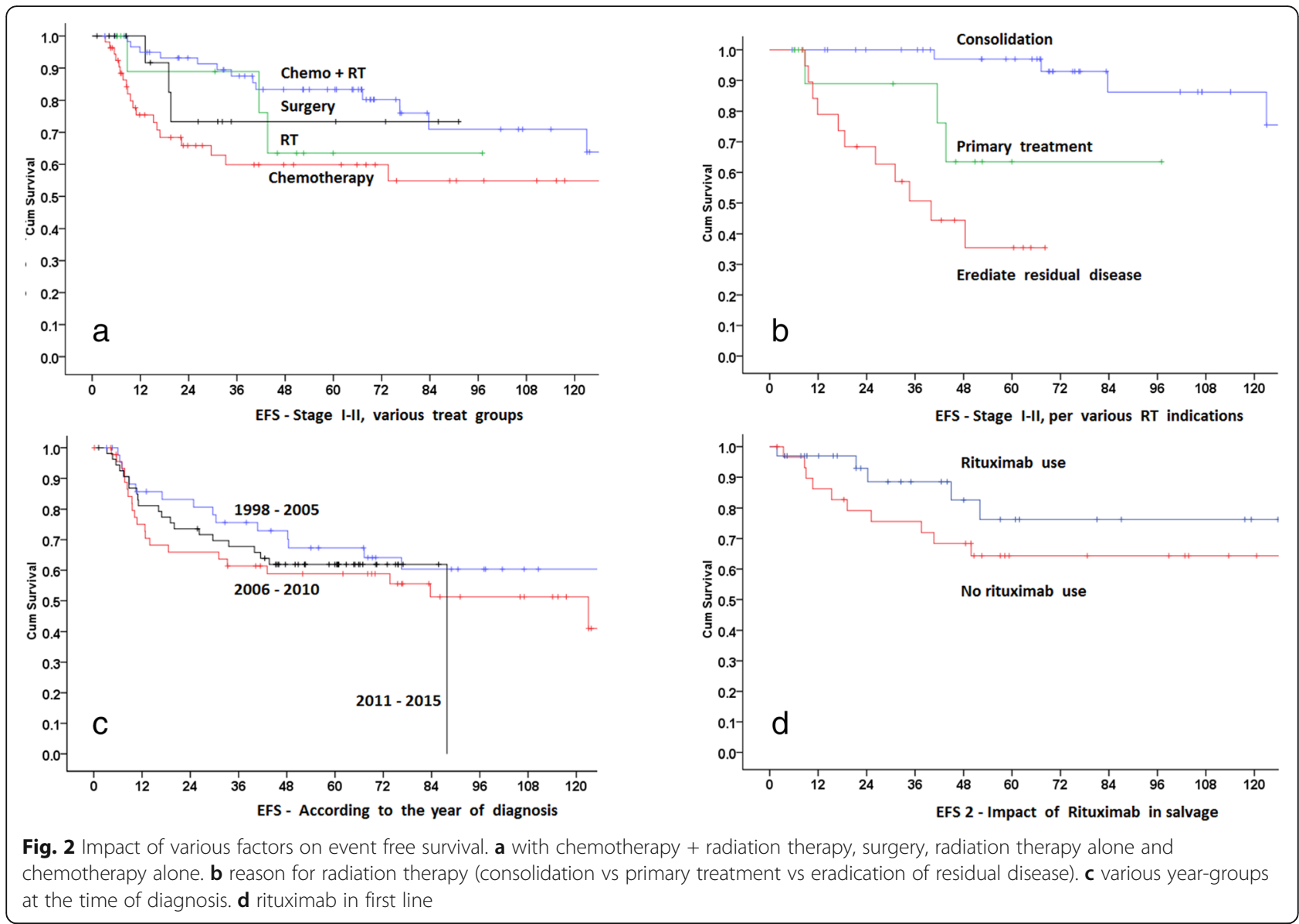

(30.4 months) was significant ( $p=<0.001)$. KM estimate of 5 and 10 years EFS for early favorable (80 and 77\%), unfavorable stage (60 and 30\%), and advanced stage (36.4 and $18 \%$ at 9 years) was significant $(p=<0.001)$. Compared to early favorable, the early unfavorable and advanced group had inferior EFS $(\mathrm{HR}=2.7, \mathrm{CI}=1-6.8$, $p=0.04)$ and $(\mathrm{HR}=4.2, \quad \mathrm{CI}=2.3-7.6, \quad p=<0.001)$ respectively.

\section{Reactive lymphadenopathy}

Fifty (25\%) patients had some form of pathologically proven reactive lymphadenopathy at some point in time. Biopsies done on clinical or radiologic suspicion of relapse/residual disease revealed 74 instances of reactive lymphadenopathy in 50 patients. Thirty-four patients had 1 biopsy specimen, 11 with 2, 3 with 3,1 each with 4 , and 5 biopsies showing reactive lymphadenopathy. Type of reactive lymphadenopathy was described in the pathology report as lymphoid hyperplasia (26 specimens), progressive transformation of germinal center (PTGC) (13 specimens), PTGC + hyperplasia (10 specimens), reactive node (24 specimens), and 1 patient as cattleman's like picture. This reactive picture was noted concurrently in the primary NLPHL diagnostic specimen at the time of initial diagnosis in 18 patients and with the relapsed specimen in 3 . In the remaining $53 \mathrm{spec}-$ imens among 29 patients, when based on the clinical and/or radiological findings of a suspected relapse, a biopsy was obtained, only a reactive picture was the primary pathological finding. 5 and 10 year EFS for patients with no hyperplasia was 63 and 54\% compared to 56 and $50 \%$ respectively in patients with hyperplasia $(p=0.99)$.

\section{High-grade transformation}

Eleven patients (5.5\%) developed transformation to an aggressive pathology after a median of 30 months (3-61 months) from the initial diagnosis. Pathology was $\mathrm{T}$ cell histiocytic rich B-cell lymphoma (a variant of DLBCL) in 6, DLBCL in 4, and classical Hodgkin lymphoma lymphocyte rich variant in 1 . Lactate dehydrogenase was elevated in 6, normal in 3, and not available in 2 patients. No other analysis was performed due to small numbers. Six patients had salvage therapy and HDC auto-SCT and another patient is in CR after salvage chemotherapy, awaiting allogeneic stem cell transplantation after failing stem cell collection. One patient with anthracycline-induced cardiomyopathy due to prior 

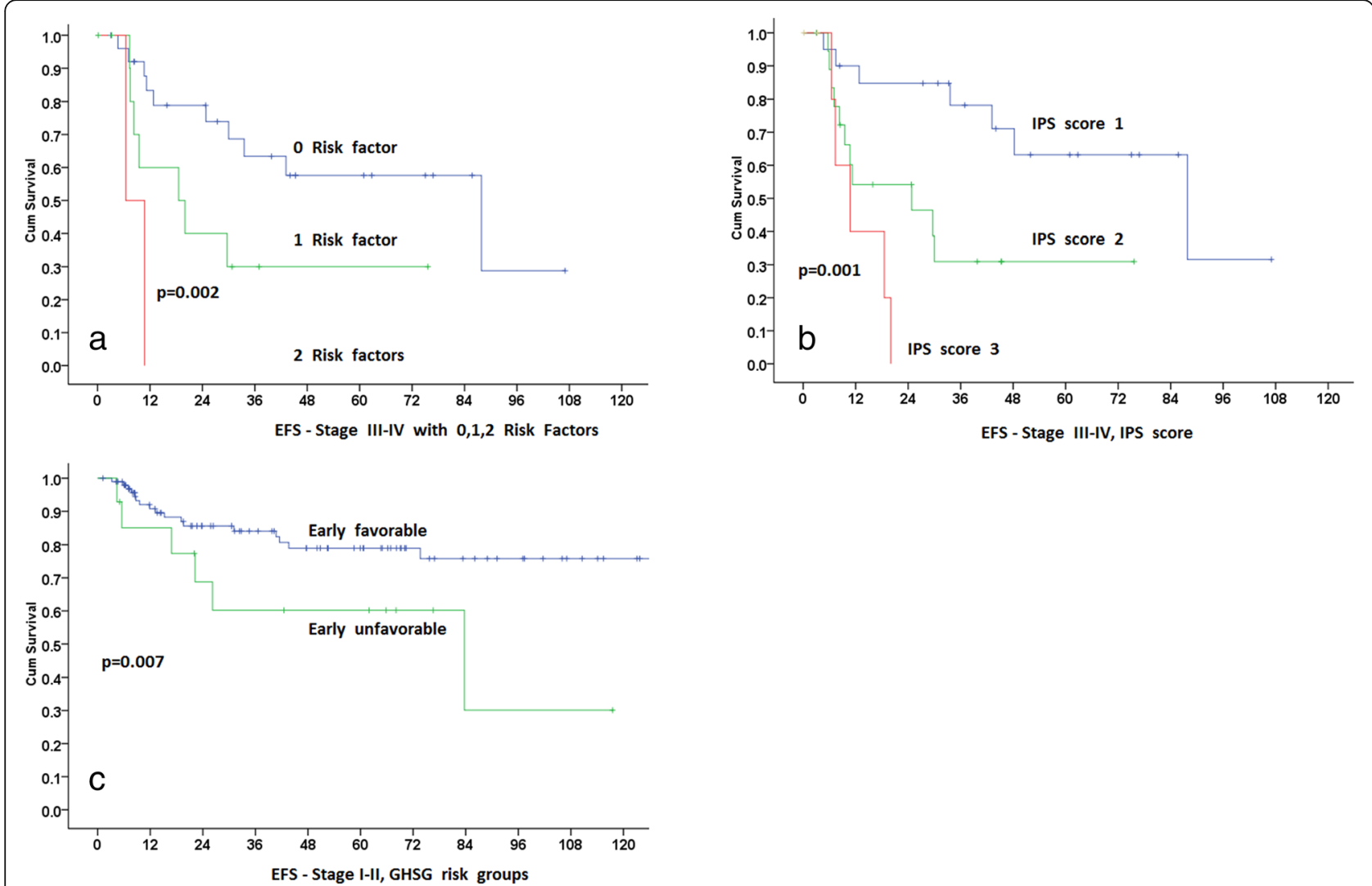

Fig. 3 Impact of various factors identified on multivariate analysis and HL- International Prognostic Score on EFS. a EFS of stage III-IV with 0, 1, 2 risk factors. b EFS and HL- International Prognostic Score. c EFS of stage I-II according to the German Hodgkin Study Group risk models; early favorable and early unfavorable

ABVD is in CR after salvage chemo. One patient refused all treatment at transformation and died 15 months after HGT. One patient was refractory to 3 lines of treatment and died 13.5 months after HGT. One patient had limited relapse in the spleen and is in CR for 10 years after splenectomy alone. Nine patients received rituximab in salvage and are alive in CR (17-150 months).

\section{Treatment failure and salvage treatment}

Ninety-five events were observed in 71 patients (Table 3). Fifty-three patients had 1 event each, 12 had 2 events each, 3 with 3 events each, and two had 4 events each. These events were persistent disease 15 times, progressive disease 29 times, 48 relapses and 1 each TRM, and death due to other causes.

\section{Management of treatment failure}

Eight of 71 patients had no further treatment; 5 of them had died, 1 TRM from first-line R-ABVD, 1 due to sickle cell-related cardiomyopathy, 3 refused any further treatment for relapsed ( 1 patient) and progressive ( 2 patients) disease. One patient relapsed in October 2016, refused any treatment, and is on observation and two patients are going through restaging workup (relapsed in November 2019).

\section{First-line failure management}

Sixty-three patients received further treatment. Fortynine/63 patients (77.8\%) received chemotherapy; 25/49 received rituximab-containing salvage combinations. Twenty patients had salvage chemotherapy followed by HDC auto-SCT. Radiotherapy alone in 5 (8\%), surgery only in $2(3 \%)$, and rituximab alone in $7(11 \%)$. Overall, 52 patients $(82.5 \%)$ went into $C R$.

\section{Second-line failure management}

Eighteen patients received treatment. Fifteen/18 patients (83.3\%) received chemotherapy; 8/15 received rituximabcontaining combinations. Eight patients had salvage chemotherapy followed by HDC auto-SCT. Radiotherapy alone in 2 (11\%) and rituximab alone in 1 (5.5\%). Overall, 12 patients $(66.6 \%)$ went into CR.

\section{Third line failure management}

Three/5 (60\%) received chemotherapy; all rituximabcontaining combinations. One patient had salvage 
Table 3 Univariate and multivariate analysis of various prognostic factors

\section{Kaplan Meier 5 years EFS and OS \\ Univariate Analysis}

Covariates / different groups

\section{Stage I-II \\ EFS}

$$
\%
$$

Female

Male

Age $<21$

Age $\geq 21$

Age $<30$

Age $\geq 30$

Performance status 0-1

Performance status $\geq 2$

B symptoms - No

B symptoms - Yes

Hemoglobin $\geq 10.5$

Hemoglobin < 10.5

Albumin $\geq 4$

Albumin $<4$

LDH not elevated

LDH elevated

Bulky disease Yes

Spleen involvement - No

Spleen involvement - Yes

Extranodal involvement - No

Extranodal involvement - Yes

Bone marrow positive

Bone marrow negative

GHSG - Early favorable

GHSG - Early Unfavorable

Radiation given

Radiation not given

Multivariate Analysis

GHSG Early favorable
GHSG Early unfavorable
Hemoglobin $\geq 10.5$
Hemoglobin $<10.5$
Albumin $\geq 4$
Albumin $<4$

Bulky disease No

$$
71.4
$$

72.2

$$
69.2
$$

71.7

0.56

$$
0.55
$$$$
\text { * }
$$

$$
\text { * }
$$$$
0.9
$$$$
0.047
$$$$
0.007
$$$$
0.59
$$$$
\text { * }
$$

$$
H R^{* *}
$$$$
1
$$$$
3.84
$$$$
-
$$

p-value

Stage III-IV

\section{EFS}

$95 \% \mathrm{Cl}^{* *}$

$1.44-10.25$

-
$\%$

21.4

40

48.4

26

45.8

18.6

33.7

0

34.4

57.1

50.5

16.7

53.8

20

67.3

19

35.5

31.8

38.6

27.1

34.7

32.8

34.2

0

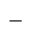

50

35

$H R$

p-value

0.82

0.151

0.29

0.54

0.54

0.98

0.011

0.005

0.012

0.26

0.058

0.34

0.35

-

4.862

1

4.359

$-$

0.27

$1.5-15.76$
Stage III-IV

OS

$\%$

91

87

95.5

81.6

97

71

87

75

88.4

87.5

86.8

67

92

70

100

75

89.2

81

89.2

84.4

87

87.5

86.4

100

75

0.91

86

95\% Cl (range)

HR

$95 \% \mathrm{Cl}$ (range)

-

- 1

*All the cases censored; no statistics performed (in stage $1-11$ performance status $>2$ in only 1 patient B symptoms - Y

1 patient.). **Hazard ratio (HR), confidence interval, Lower - Upper limits (CI), other abbreviation as per Table 1. ***no factor showed significance on 
chemotherapy followed by HDC auto-SCT. Radiotherapy alone in $2(40 \%)$. Three patients $(60 \%)$ went into CR.

Overall, rituximab was used in the salvage setup in $42 /$ 63 patients $66.6 \%$ (33 in the first line salvage and another 11 in subsequent treatment failures).

\section{HDC auto-SCT}

Twenty-nine patients underwent HDC auto-SCT. As stated above, 20 at 1st, 8 at 2nd, and 1 at 3rd failure. 23/29 had carmustine, etoposide, cytarabine, and melphalan (BEAM) as HDC. CR was observed in 27 (93\%) patients and PR in 2 (7\%). 4 patients observed treatment failures. Two patients relapsed; one went into $\mathrm{CR}$ with rituximab alone and the other received 3 more lines including rituximab maintenance for 24 months and is in CR. One PR patient went into $\mathrm{CR}$ after radiation and one PR was observed for 9 years for slowly progressing disease, had salvage chemo, and progressed again. He is on observation again. All 29 patients are alive, and 28 patients are in CR. 20/29 (69\%) patients received rituximab at some point in time. The most commonly used salvage was ESHAP (etoposide, solumedrol, Ara-C, and cisplatin) in 22/29 patients.

\section{Impact of various prognostic factors on the outcome}

We evaluated different prognostic, clinical, and laboratory factors and also performed multivariate analysis as shown in Table 3 and Fig. 3. Gender has no impact on EFS; EFS at 5 years for males (62\%) and females (59\%), $(\mathrm{HR}=1.17, \mathrm{CI}=0.67-2, p=0.56)$.

We divided the age at diagnosis into various groups and evaluated its impact on EFS. There was no difference in the type of treatment for these groups $(p=0.9)$. EFS at 5 years for patients age $<21 \mathrm{vs}>21$ years $(p=0.52)$ or $<30$ or $>30$ years $(p=0.72)$ was similar. For patients age $<14$ years (52.5\%), > 14-21 (73.7\%), > 21-30 (59\%), 30-50 (61.6.4\%) and for $>50(53 \%)$ failed to show a statistically significant trend ( $p=0.22$, Log-Rank method). Although, Pairwise analysis did show that age group 14-21 has superior EFS compared to $<14$ group $(p=0.016)$ but not with other groups. Cox Regression for age group 14-21 favored better outcome compared to age $<14$, $(\mathrm{HR}=0.44,95 \% \mathrm{CI}=0.22$ $0.88, p=0.02)$. For ages $21-30(\mathrm{HR}=0.5), 30-50(\mathrm{HR}=$ $0.4)$ and age $>50(H R=0.62)$ was not significant.

We also analyzed the impact of the year of diagnosis. Patients diagnosed in 2016 onwards were excluded as they had a significantly shorter follow-up. One hundred forty-five patients (1998 to 2015) were divided into three groups according to the year of diagnosis. From 1998 to 2015, treatment was similar without rituximab (only 6 received rituximab as the first line during this time). Five year EFS according to the year of diagnosis group was similar for 1998-2004 (64\%), 2005-2009 (59\%) and 2010-2015 (62\%), $(p=0.33)$.
Multivariate analysis for stage I-II identified GHSG risk group model of early favorable and early unfavorable $(p=0.007)$ as the most significant risk factor (Fig. 3c). For stage III-IV, albumin and hemoglobin levels $(\mathrm{p}=$ 0.007 ) were significant, and based on these two factors, we divided patients into 0,1 and 2 risk groups for EFS (Fig. 3a). We also plotted EFS for stages III-IV based on HL- International Prognostic Score (Fig. 3b) that showed significance too $(p=0.001)$. This variable cannot be included in the multivariate analysis as the International Prognostic Score scoring incorporated many factors already included in univariate analysis. The cures of these two models (Fig. 3a and b) are very similar.

\section{Discussion}

Despite the rarity of the condition, we believe, we are reporting the largest single-institution data to date. Our data includes detailed patient characteristics, risk factors, primary and subsequent salvage treatments including HDC auto-SCT, but also an important observation of reactive lymphadenopathy. There are limited studies in the last 20 years, reporting around 100 or more patients [3$8,18,19]$, mostly from various national registries, pooled multi-institutional data, or subgroup analysis from cooperative HL trials. These studies have provided large data with varying details on patient characteristics, treatments, and outcomes. We have included these large studies in Table 4 as a reference, only the most recent study is included in case of repeat/updated reports.

Like most of the studies, we have observed the same gender distribution of Male:female of 3:1. The median age of our patients at diagnosis is 22 years with half of the patients $<21$ years at diagnosis. Even for patients > 14 years, our median age is 25.7 years ( $14-79$ years). This is significantly different from other reports (Table 4). This is a reflection of the significantly large young population in the Kingdom of Saudi Arabia (as well as in the Middle East) as reported before [30]. Given the relatively small number of females and different age distribution as stated above, we failed to observe any EFS difference due to gender and age at diagnosis as shown in some other studies (Table 4). We also failed to show the negative impact of older age on various survival outcomes due to the same reason / limited older population.

We observed the same stage distribution as others, almost $>3 / 4$ with stages I-II. Despite the increasing use of FDG-PET/CT scan from 2010 to 2019 for initial staging, we observed no change in the staging trend from the earlier period.

We treated our patients according to uniform guidelines that are updated frequently. NLPHL was treated as classical Hodgkin lymphoma (cHL) protocols. ABVD was the mainstay of chemotherapy (87\%), although, for the past few years, we are increasingly using the non-anthracycline- 
Table 4 Literature review of large NLPHL studies

\begin{tabular}{|c|c|c|c|c|c|c|c|c|c|c|}
\hline $\begin{array}{l}\text { Study } \\
\text { (Publication } \\
\text { year) }\end{array}$ & $\begin{array}{l}\text { Study } \\
\text { Design } \\
\text { (years of } \\
\text { treatment) }\end{array}$ & Numbers & $\begin{array}{l}\text { Stage / } \\
\text { population }\end{array}$ & $\begin{array}{l}\text { Modality } \\
\text { of } \\
\text { Treatment }\end{array}$ & $\begin{array}{l}\text { Median } \\
\text { Follow } \\
\text { up }\end{array}$ & PFS / EFS & OS & $\begin{array}{l}\text { Rx for } \\
\text { failure } \\
\text { or } 2 n d \\
\text { line Rx }\end{array}$ & $\begin{array}{l}\text { Median } \\
\text { age } \\
\text { (range) }\end{array}$ & Comments \\
\hline $\begin{array}{l}\text { Diehl et al. } \\
1999 \text { [20] }\end{array}$ & $\begin{array}{l}\text { Retrospective } \\
\text { 1980s }\end{array}$ & 219 & Stage I-IV & All & 6.8 & $\begin{array}{l}\text { NA ( } 8 \\
\text { years) }\end{array}$ & & No & $\begin{array}{l}35(16- \\
N A)\end{array}$ & $\begin{array}{l}17 \text { international } \\
\text { centers. Treated in } \\
1980 \text { s. MOPP based } \\
\text { therapy. Compared } \\
\text { NLPHL vs lymphocyte } \\
\text { rich variant. }\end{array}$ \\
\hline
\end{tabular}

$\begin{array}{cccc}\text { I } & 85 \% & 99 \\ \text { II } & 71 \% & 94 \\ \text { III } & 62 \% & 94 \\ \text { IV } & 24 \% & 41\end{array}$

Wirth et al. Retrospective $202 \quad$ Stage I-I- RT

(2005) [21] 1969-1995

Stage I-II RT

15

$82 \%(15$

99

94

41

Nogova'

et al. (2008)

[18]

$\begin{array}{lllll} & & \begin{array}{l}\text { early Favor } \\ \text { early unfav } \\ \text { advanced }\end{array} \\ & & & \\ & & \text { Stage I-II } & \text { RT, CMT, } 136 \\ \text { Chen et al. } & \text { Retrospective } 113 & & \text { CT } \\ \text { (2010) [22] } & 70-2005 & & & \end{array}$

$93 \%$

$87 \%$

$77 \%$

(2010) [22] 70-2005

\section{at 10 years}

$83 \%(15$ years)

Yes

$31(2-$
$79)$

(2)

aears, $\mathrm{B}$ symptoms, involved sites with inferior OS.

GHSG HD12 and HD14. Inferior PFS with advanced stage, low $\mathrm{Hb}$ and lymphopenia. Study to compare NLPHL vs $\mathrm{CHL}$, showed better outcome for NLPHL than $\mathrm{CHL}$

\begin{tabular}{|c|c|c|c|c|c|c|c|c|c|c|}
\hline & & & Stage I & & & $85 \%$ & $96 \%$ & & & \\
\hline & & & Stage II & & & $61 \%$ & $100 \%$ & & & \\
\hline \multirow[t]{3}{*}{$\begin{array}{l}\text { Biasoli et al. } \\
\text { (2010) [3] }\end{array}$} & \multirow[t]{3}{*}{$\begin{array}{l}\text { Retrospective } \\
\text { (1973-2003) }\end{array}$} & \multirow[t]{3}{*}{164} & \multirow[t]{3}{*}{ Stage I-IV } & & $9.5 \mathrm{yrs}$ & $\begin{array}{l}60 \%(10 \\
y r s)\end{array}$ & $91 \%$ (10yrs) & Yes & $\begin{array}{l}30(6- \\
69)\end{array}$ & $\begin{array}{l}\text { French centers, } 158 \\
\text { stage I-II. } 11.6 \% \text { had } \\
\text { transformation }\end{array}$ \\
\hline & & & & any $R x$ & & $66 \%$ & $93 \%$ & & & \\
\hline & & & & No Rx & & $41 \%$ & $91 \%$ & & & \\
\hline $\begin{array}{l}\text { Solanki et al. } \\
2013 \text { [23] }\end{array}$ & $\begin{array}{l}\text { Retrospective } \\
\text { 1988-2009 }\end{array}$ & 469 & Stage I-II & NA & $6 y r s$ & NA & $88 \%$ & No & $\begin{array}{l}37[4- \\
88]\end{array}$ & $\begin{array}{l}\text { SEER data USA. older } \\
\text { age, female gender, } \\
\text { multiple nodal } \\
\text { regions and B- } \\
\text { symptoms with infer- } \\
\text { ior OS. }\end{array}$ \\
\hline \multirow[t]{3}{*}{$\begin{array}{l}\text { Eichenauer } \\
\text { et al. (2015) } \\
\text { [24] }\end{array}$} & \multirow[t]{3}{*}{$\begin{array}{l}\text { Retrospective } \\
\text { 1988-2009 }\end{array}$} & 256 & \multirow[t]{3}{*}{ Stage IA } & & $91 \mathrm{~m}$ & $\begin{array}{l}88.9 \%(8 \\
\text { years) }\end{array}$ & $\begin{array}{l}98.2(8 \\
\text { years) }\end{array}$ & No & $\begin{array}{l}39(16- \\
75)\end{array}$ & $\begin{array}{l}\text { GHSG 1988-2009 } \\
\text { studies. All have } \\
\text { similar tumor control. } \\
\text { IFRT with less toxicity. }\end{array}$ \\
\hline & & 72 & & CMT & 95 & $\begin{array}{l}88.5 \%(8 \\
\text { years) }\end{array}$ & $\begin{array}{l}98.6 \%(8 \\
\text { years) }\end{array}$ & & & \\
\hline & & 49 & & EFRT & 110 & $\begin{array}{l}84.3 \% \text { ( } 8 \\
\text { years) }\end{array}$ & $\begin{array}{l}95.7 \%(8 \\
\text { years) }\end{array}$ & & & \\
\hline
\end{tabular}


Table 4 Literature review of large NLPHL studies (Continued)

\begin{tabular}{|c|c|c|c|c|c|c|}
\hline $\begin{array}{l}\text { Study } \\
\text { (Publication } \\
\text { year) }\end{array}$ & $\begin{array}{l}\text { Study } \\
\text { Design } \\
\text { (years of } \\
\text { treatment) }\end{array}$ & Numbers & $\begin{array}{l}\text { Stage / } \\
\text { population }\end{array}$ & $\begin{array}{l}\text { Modality } \\
\text { of } \\
\text { Treatment }\end{array}$ & $\begin{array}{l}\text { Median } \\
\text { Follow } \\
\text { up }\end{array}$ & PFS / EFS \\
\hline & & 108 & & IFRT & 87 & $\begin{array}{l}91.9 \%(8 \\
\text { years) }\end{array}$ \\
\hline & & 27 & & Rituximab & 49 & $\begin{array}{l}81 \%(4 \\
\text { years) }\end{array}$ \\
\hline $\begin{array}{l}\text { Gerber et al. } \\
2015 \text { [25] }\end{array}$ & $\begin{array}{l}\text { Retrospective } \\
\text { 1988-2010 }\end{array}$ & 1162 & Stage I-IV & NA & $7 y r s$ & NA \\
\hline \multirow[t]{4}{*}{$\begin{array}{l}\text { Lazarovici } \\
\text { et al. (2015) } \\
\text { [5] }\end{array}$} & $\begin{array}{l}\text { Retrospective } \\
\text { (1974-2012) }\end{array}$ & 314 & Stage I-IV & All & $55.8 \mathrm{~m}$ & $\begin{array}{l}44.2 \%(10 \\
y r s)\end{array}$ \\
\hline & & & & $\mathrm{CT}$ & & $\begin{array}{l}78.8 \%(4 \\
y r s)\end{array}$ \\
\hline & & & & RT & & $\begin{array}{l}79.6 \%(4 \\
y r s)\end{array}$ \\
\hline & & & & CMT & & $\begin{array}{l}93.9 \%(4 \\
\text { yrs) }\end{array}$ \\
\hline $\begin{array}{l}\text { Parikh et al. } \\
2016[26]\end{array}$ & $\begin{array}{l}\text { Retrospective } \\
1998-2011\end{array}$ & 1016 & Stage I-II & & $6.6 \mathrm{yrs}$ & NA \\
\hline
\end{tabular}

No RT

Yes RT

Kenderian et al. 2016 [8]
Retrospective 222 1970-2011
Stage I-IV

(a)

HGT

No HGT

Molin et al. (2017) [27]

Retrospective 158 (2000-2014)

\section{(2017) [27]}

$\begin{array}{llllll} & & \begin{array}{l}\text { Stages I-IIA } \\ \text { stages IIB-IV }\end{array} & & \\ \text { Shivarov } & \text { Retrospective } 1401 & \text { Stage I-IV } & \text { NA } & \text { NA } \\ 2018[28] & (2000-2014) & & & & \end{array}$

$88.10 \%$

$94.10 \%$

$$
16.3 \text { yrs NA }
$$

76.4 (5 yrs)

similar as transformed

94 and $79 \% \quad$ No (5-10 yrs)
98 and $85 \%$

87 and $67 \%$
48 (16- Swedish Cancer 88) male Registry. No survival 44 benefit of RT vs CMT female in stages I-IIA. Rituxi- 59 mab with chemo su- perior to chemo alone in IIB-IV patients.

ayo Clinic. Focused on HGT, 8.1\% HGT at a median of 35 months, $76 \% 5$ yr OS. No difference in OS of HGT vs no HGT NLPH L pts.
38 (not SEER data USA. A
Population-Based ana- No info related to
(ligum). 82.5 stages -II. Transformation

National Data Base impact of RT, showed that RT use with better OS.

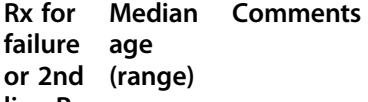

43 (16-

92) male

41

female

48
SEER data USA. OS extracted from the figure. Older age, stage III-IV and not using RT with inferior OS. Female older at Dx. 
Table 4 Literature review of large NLPHL studies (Continued)

\begin{tabular}{|c|c|c|c|c|c|c|c|c|c|c|}
\hline $\begin{array}{l}\text { Study } \\
\text { (Publication } \\
\text { year) }\end{array}$ & $\begin{array}{l}\text { Study } \\
\text { Design } \\
\text { (years of } \\
\text { treatment) }\end{array}$ & Numbers & $\begin{array}{l}\text { Stage / } \\
\text { population }\end{array}$ & $\begin{array}{l}\text { Modality } \\
\text { of } \\
\text { Treatment }\end{array}$ & $\begin{array}{l}\text { Median } \\
\text { Follow } \\
\text { up }\end{array}$ & PFS / EFS & OS & $\begin{array}{l}\text { Rx for } \\
\text { failure } \\
\text { or 2nd } \\
\text { line } R x\end{array}$ & $\begin{array}{l}\text { Median } \\
\text { age } \\
\text { (range) }\end{array}$ & Comments \\
\hline \multirow[t]{5}{*}{$\begin{array}{l}\text { Alonso et al. } \\
\text { (2018) [29] }\end{array}$} & $\begin{array}{l}\text { Retrospective } \\
\text { (2004-2012) }\end{array}$ & 1420 & Stage I-II & & $48.3 \mathrm{~m}$ & NA & (10 years) & No & $\begin{array}{l}45 \text { RT } \\
\text { gp, } 48 \\
\text { No RT } \\
\text { gp }\end{array}$ & $\begin{array}{l}\text { National Data Base } \\
\text { (USA). Age > } 60 \text { and } \\
\text { not using RT with } \\
\text { inferior OS. }\end{array}$ \\
\hline & & & & No Rx & & & $87 \%$ & & 48 & \\
\hline & & & & $C T$ & & & $80 \%$ & & 48 & \\
\hline & & & & RT & & & $93 \%$ & & 45 & \\
\hline & & & & CMT & & & $92 \%$ & & 45 & \\
\hline \multirow[t]{6}{*}{$\begin{array}{l}\text { Posthuma } \\
\text { et al. (2019) } \\
\text { [19] }\end{array}$} & $\begin{array}{l}\text { Retrospective } \\
\text { (1993-2016) }\end{array}$ & 687 & Stage I-IV & All & $7.7 \mathrm{yrs}$ & NA & (5-10yrs) & No & $4-87$ & $\begin{array}{l}\text { Netherland Cancer } \\
\text { Registry. Increase in } \\
\text { median age over } \\
\text { time. No excess } \\
\text { mortality compared } \\
\text { to general population } \\
\text { in pts. age 18-39. }\end{array}$ \\
\hline & & & Stage I-II & No Rx & & & $93-80 \%$ & & $\begin{array}{l}42 \\
(2003- \\
2016)\end{array}$ & \\
\hline & & & & RT & & & 99-99\% & & & \\
\hline & & & & $\begin{array}{l}\text { Chemo } \\
+/- \text { RT }\end{array}$ & & & $90-89 \%$ & & & \\
\hline & & & stage III-IV & No Rx & & & $61-57 \%$ & & & \\
\hline & & & & $\begin{array}{l}\text { Chemo } \\
\text { +/- RT }\end{array}$ & & & $89-80 \%$ & & & \\
\hline \multirow[t]{7}{*}{$\begin{array}{l}\text { Borchmann } \\
\text { et al. (2019) } \\
\text { [4] }\end{array}$} & $\begin{array}{l}\text { Retrospective } \\
\text { (1974-2016) }\end{array}$ & 163 & Stage I-IV & All & $69 m$ & $85 \%$ (5 yrs) & $99 \%$ (5 yrs) & & $\begin{array}{l}40(16- \\
75)\end{array}$ & $\begin{array}{l}\text { Memorial Sloan } \\
\text { Kettering USA, } \\
\text { transformation 7.4\% } \\
\text { at } 7 \text { years median. } \\
\text { Shorter PFS with } \\
\text { extranodal and bulky } \\
\text { disease } \geq 5 \mathrm{~cm} \text {. Non } \\
\text { RT Rx with inferior } \\
\text { PFS }\end{array}$ \\
\hline & & & & No Rx & & $77 \%$ & $100 \%$ & Yes & & \\
\hline & & & & any $R x$ & & $87 \%$ & $98 \%$ & & & \\
\hline & & & Early stage & No Rx & & $65 \%$ & & & & \\
\hline & & & & any $R x$ & & $94 \%$ & & & & \\
\hline & & & & With RT & & $94 \%$ & & & & \\
\hline & & & & without RT & & $73 \%$ & & & & \\
\hline \multirow[t]{4}{*}{$\begin{array}{l}\text { Eichenauer } \\
\text { et al } 2019 \text { [6] }\end{array}$} & Retrospective & 471 & Stage I-IV & & $9.2 \mathrm{yrs}$ & $75.5 \%$ & $92.10 \%$ & & $\begin{array}{l}39(16- \\
75)\end{array}$ & $\begin{array}{l}\text { GHSG HD7 to HD15. } \\
\text { HGT } 2.54 \% .23 \% \text { of all } \\
\text { deaths due to NLPHL }\end{array}$ \\
\hline & & & early Favor & & & $79.7 \%$ & $93.30 \%$ & & & \\
\hline & & & early unfav & & & $72.1 \%$ & $96.20 \%$ & & & \\
\hline & & & advanced & & & $69.8 \%$ & $87.40 \%$ & & & \\
\hline \multirow[t]{4}{*}{$\begin{array}{l}\text { Wilson et al. } \\
2019 \text { [7] }\end{array}$} & $\begin{array}{l}\text { Retrospective } \\
\text { (2004-2014) }\end{array}$ & 233 & Stage I-IV & All & 8.6 & $\begin{array}{l}88 \% \\
\text { (estimated) }\end{array}$ & 97\% (5 yrs) & No & $\begin{array}{l}43(<16 \\
\text { only } 5 \%)\end{array}$ & $\begin{array}{l}\text { Multi-institution from } \\
\text { UK. HGT 6\%. }\end{array}$ \\
\hline & & & & No Rx & & & $96.70 \%$ & & & \\
\hline & & & & RT & & & 98.3 & & & \\
\hline & & & & $\begin{array}{l}\text { RT +/- } \\
\text { chemo }\end{array}$ & & & 95.2 & & & \\
\hline
\end{tabular}


Table 4 Literature review of large NLPHL studies (Continued)

\begin{tabular}{|c|c|c|c|c|c|c|c|c|c|c|}
\hline $\begin{array}{l}\text { Study } \\
\text { (Publication } \\
\text { year) }\end{array}$ & $\begin{array}{l}\text { Study } \\
\text { Design } \\
\text { (years of } \\
\text { treatment) }\end{array}$ & Numbers & $\begin{array}{l}\text { Stage / } \\
\text { population }\end{array}$ & $\begin{array}{l}\text { Modality } \\
\text { of } \\
\text { Treatment }\end{array}$ & $\begin{array}{l}\text { Median } \\
\text { Follow } \\
\text { up }\end{array}$ & PFS / EFS & OS & $\begin{array}{l}\text { Rx for } \\
\text { failure } \\
\text { or } 2 n d \\
\text { line } R x\end{array}$ & $\begin{array}{l}\text { Median } \\
\text { age } \\
\text { (range) }\end{array}$ & Comments \\
\hline \multirow[t]{5}{*}{ Current study } & $\begin{array}{l}\text { Retrospective } \\
\text { 1998-2019 }\end{array}$ & 200 & Stage I-IV & All & 5 & $\begin{array}{l}62.3 \% \& \\
54 \%[5-10]\end{array}$ & $\begin{array}{l}94.8 \% \& \\
92.4(5-10)\end{array}$ & Yes & $\begin{array}{l}22(4- \\
79)\end{array}$ & $\begin{array}{l}\text { Single institution. } \\
\text { Chemo + RT with } \\
\text { better EFS than } \\
\text { chemo alone. High } \\
\text { incidence of familial } \\
\text { malignancies, large } \\
\text { numbers with HDC } \\
\text { auto-SCT, }\end{array}$ \\
\hline & & & I & & & $\begin{array}{l}72 \%(10 \\
\text { yrs) }\end{array}$ & 97.7 & & & \\
\hline & & & $\|$ & & & $55.7 \%$ & 97.7 & & & \\
\hline & & & III & & & $20 \%$ & 87.6 & & & \\
\hline & & & IV & & & $26.8 \%$ & 79.5 & & & \\
\hline
\end{tabular}

Abbreviations: Same as Tables 1 and 2, PFS Progression free survival, EFS Event free survival, Rx Treatment, GHSG German Hodgkin Lymphoma Study Group, SEER Surveillance, Epidemiology, and End Results, CMT Combined modality treatment, EFRT Extended field RT, IFRT Involved field RT, HGT High grade transformation

based treatment for early stages, i.e. rituximab + CVP or a $\mathrm{CHOP}$ based treatment for advanced stages. As the treatment and survival outcomes are different for stage I-II vs III-IV, we have reported them separately. Patients with stages I-II were mainly treated with chemotherapy + RT. This is relatively different from many studies where mostly RT alone was used as the primary treatment modality. One of the main reasons was to minimize/avoid radiation in our young patient population. Overall survival outcome is similar for this group regardless of treatment arm, although the use of RT resulted in superior EFS compared to chemotherapy alone group. We also reported differences in the outcome of stage I-II patients who received RT according to the reason for the use of RT. RT use showed a 5-year EFS of $97 \%$ in patients who were already in CR after chemotherapy vs $63 \%$ EFS when used as primary/first-line treatment vs $36 \%$ for the eradication of residual disease after chemotherapy. For stages III-IV, due to relatively small numbers of uniformly treated patients (chemotherapybased), no subgroup analysis was performed. Rituximab alone, or in combination with ABVD was not used in the primary/salvage treatment according to the approved treatment guidelines at that time. Unexpected pulmonary toxicity resulted in the death of two patients in CR on Rituximab + ABVD resulting in the reluctance to use rituximab. The impact of rituximab in our patient population should be interpreted with caution. There are a wide variety of clinical scenarios, timing, type, and intensity of salvage and all these have a significant impact on the outcome. Given the small number of patients in each rituximabreceiving group in our cohort, the magnitude of true benefit remains unclear. At the same time, clinical trials are unlikely to be conducted in this setup due to the safety and efficacy of rituximab. In the salvage setup, we used ESHAP, lately with rituximab as our primary salvage chemotherapy for patients going for HDC auto-SCT [9]. We previously reported seventeen patients who underwent HDC auto-SCT data and now total HDC auto-SCT patients have reached twenty-nine [9]. This is one of the largest single-institution experiences of NLPHL and HDC auto-SCT that proves the benefit of this strategy for patients with refractory NLPHL. Detailed information on multiple lines of treatment makes our data a nice reference.

We also tried to explore the impact of various factors using multivariate analysis. For stages I-II, we identified GHSH group of early favorable and early unfavorable as discriminatory for the EFS. For stages III-IV, hemoglobin and albumin levels were significant and we were able to draw a risk-based EFS graph. Given the small numbers, this should be taken with caution. We also observed that HL- International Prognostic Score based model for EFS has the same outcome and most likely will a better choice to validate in a larger group of stages III-IV.

We reported 5.5\% HGT, this is in line with many other studies in Table 3 (6 to $11.6 \%$ ), except for one GHSG study with a lower incidence of $2.45 \%$ HGT6. These HGT patients have excellent OS as reported in other studies. Most of our patients with HGT received HDC auto-SCT. Longer follow-up is needed for those patients who have relatively short follow-up / less than 5 years of follow-up for an accurate incidence of HGT.

A quarter of our patients had some form of pathologically proven reactive lymphadenopathy at some point in time. In the era of FDG-PET/CT scan, these findings are likely to be more and a change in the treatment strategy should be made only after a pathological confirmation. This is especially true when HGT is also a concern in NLPHL. There are reports with a limited number of patients with this observation [31-34]. 


\section{Conclusion}

In brief, our data has shown that NLPHL presentation has both similarities and differences in the Middle East. Younger age at the presentation in our patients has its impact on treatment decisions and likely long-term survival. FDG-PET/CT scan has not resulted in stage migration. For early stages, various treatment strategies have no impact on overall survival, though treatment failure was less common for those who received chemotherapy + RT compared to chemotherapy alone. A large number of patients had FHM that warrants genetic studies. Lymphoid hyperplasia may mimic a relapse and proper pathological confirmation is important before changing a treatment plan.

\begin{abstract}
Abbreviations
NLPHL: Nodular lymphocyte-predominant Hodgkin lymphoma; KM: KaplanMeier; RT: Radiation therapy; ABVD: Adriamycin, bleomycin, vinblastin, dacarbazine; OS: Overall survival; EFS: Event free survival; HL: Hodgkin lymphoma; LP cells: Lymphocyte-predominant cells"; NHL: Non-Hodgkin lymphoma; DLBCL: Diffuse large B cell lymphoma; HDC auto-SCT: High dose chemotherapy and auto-SCT; HGT: High-grade transformation; PR: Partial response; SD: No response (NR)/ stable disease; PD: Progressive disease; CR: Complete remission; CRu: CR unconfirmed; EFRT: Extended field RT; IFRT: Involved field RT; ISRT: Involved site RT; VMAT: Volumetric modulated arc therapy; IMRT: Intensity-modulated RT; FDG-PET/CT: ${ }^{18} \mathrm{~F}-$

fluorodeoxyglucose positron emission tomography; WHO: The World Health Organization; GHSG: German Hodgkin Study Group; COPP/

MOPP: Cyclophosphamide / mechlorethamine, vincristine, procarbazine, prednisone; R-CHOP: Rituximab + cyclophosphamide, adriamycin, vincristine, prednisone; CVP: Cyclophosphamide, vincristine, prednisone; HR: Hazard ratio; Cl: Confidence interval; CHL: Classical Hodgkin lymphoma;

SEER: Surveillance, Epidemiology, and End Results; CMT: Combined modality treatment
\end{abstract}

\section{Acknowledgements}

We appreciate Ms. Cherry ColCol for data capturing and entering, Dr. Abida Rehman for data capturing.

\section{Clinical trial information}

Not a clinical trial.

All procedures followed were in accordance with the ethical standards of the responsible committee on human experimentation (institutional and national) and with the Helsinki Declaration of 1975, as revised in 2008.

\section{Authors' contributions}

All authors have read and approved the manuscript. SA was the principal investigator, analysis of the data and takes primary responsibility for the paper; SR, IM helped in data collection, interpretation, analysis and in manuscript writing, SS and MAE collected data and helped in manuscript writing. TAME performed statistical analysis and helped in manuscript writing, YK collected and analyzed radiation therapy related data and helped in manuscript writing. AA and SAI S collected pediatrics patient's data, helped in the analysis of data and manuscript writing, JN and AHM collected and entered data and helped in the analysis. MS and NB reviewed the pathology specimens and helped and manuscript writing. SAI S currently working at the Jordan University of Science \& Technology, Amman, Jordan. MAE is also an assistant professor of Clinical Oncology, Faculty of Medicine, Menoufia University, Egypt.

\section{Funding}

No Research grant or support for this project.

\section{Availability of data and materials}

All authors had full access to all data and approved this submission. The datasets used and/or analyzed during the current study are available from the corresponding author on reasonable request. Data sharing: Data is a "retrospective/prospective database" and is owned by the institution. This data is under the custody of the principal and co-investigators as per the Institutional Research Advisory Counsel and Research Ethics Committee guidelines. It is not available to the public for sharing. Full or part of this data can be shared after an official request / approval of the institutional Research Advisory Counsel and Research Ethics Committee.

\section{Declarations}

\section{Ethics approval and consent to participate}

Approved by Institutional "Research Advisory Council (RAC)". King Faisal Specialist Hospital \& Research Center, Riyadh, Kingdom of Saudi Arabia. RAC project \# 2021-048 lymphoma database. Waiver of signed consent as per RAC (no individual patient identified data / no pictures / verbal consent documented on paper or electronic chart). This waiver of signed consent was for participation in the database collection study and subsequent publications as per RAC guidelines.

\section{Consent for publication}

Not applicable.

\section{Competing interests}

None.

\section{Author details}

${ }^{1}$ Oncology Center, King Faisal Specialist Hospital and Research Center, Riyadh, Kingdom of Saudi Arabia. 'Department of Pediatric Hematology/ Oncology, King Faisal Specialist Hospital and Research Center, Riyadh, Kingdom of Saudi Arabia. ${ }^{3}$ AlFaisal University, Riyadh, Kingdom of Saudi Arabia. ${ }^{4}$ Pathology and Laboratory Medicine, King Faisal Specialist Hospital and Research Center, Riyadh, Kingdom of Saudi Arabia.

Received: 24 March 2020 Accepted: 21 March 2021

Published online: 01 April 2021

\section{References}

1. Swerdlow SH, Campo E, Pileri SA, Harris NL, Stein H, Siebert R, et al. The 2016 revision of the World Health Organization classification of lymphoid neoplasms. Blood. 2016;127(20):2375-90. e-pub ahead of print 2016/03/17. https://doi.org/10.1182/blood-2016-01-643569.

2. Harris NL, Jaffe ES, Stein H, Banks PM, Chan JK, Cleary ML, et al. A revised European-American classification of lymphoid neoplasms: a proposal from the International Lymphoma Study Group. Blood. 1994;84(5):1361-92 e-pub ahead of print 1994/09/01.

3. Biasoli I, Stamatoullas A, Meignin V, Delmer A, Reman O, Morschhauser F, et al. Nodular, lymphocyte-predominant Hodgkin lymphoma: a long-term study and analysis of transformation to diffuse large B-cell lymphoma in a cohort of 164 patients from the Adult Lymphoma Study Group. Cancer. 2010;116(3):631-9. e-pub ahead of print 2009/12/24. https://doi.org/10.1002/ cncr.24819.

4. Borchmann S, Joffe E, Moskowitz CH, Zelenetz AD, Noy A, Portlock CS, et al. Active surveillance for nodular lymphocyte-predominant Hodgkin Iymphoma. Blood. 2019;133(20):2121-9. e-pub ahead of print 2019/02/17. https://doi.org/10.1182/blood-2018-10-877761.

5. Lazarovici J, Dartigues P, Brice P, Oberic L, Gaillard I, Hunault-Berger M, et al. Nodular lymphocyte predominant Hodgkin lymphoma: a Lymphoma Study Association retrospective study. Haematologica. 2015;100(12):1579-86. e-pub ahead of print 2015/10/03. https://doi.org/10.3324/haematol.2015.133025.

6. Eichenauer DA, Plutschow A, Fuchs M, Sasse S, Baues C, Boll B, et al. LongTerm Follow-Up of Patients With Nodular Lymphocyte-Predominant Hodgkin Lymphoma Treated in the HD7 to HD15 Trials: A Report From the German Hodgkin Study Group. J Clin Oncol. 2019: JCO1900986. e-pub ahead of print 2019/10/19;38:698-705. https://doi.org/10.1200/jco.19.00986.

7. Wilson MR, Bagguley T, Smith A, Roman E, Patmore R, Hanlon K, et al. Frontline management of nodular lymphocyte predominant Hodgkin lymphoma - a retrospective UK multicentre study. Br J Haematol. 2019;186(6):e214-7. e-pub ahead of print 2019/07/26. https://doi.org/10.1111/bjh.16109.

8. Kenderian SS, Habermann TM, Macon WR, Ristow KM, Ansell SM, Colgan JP, et al. Large B-cell transformation in nodular lymphocyte-predominant Hodgkin lymphoma: 40-year experience from a single institution. Blood. 2016;127(16):1960-6. e-pub ahead of print 2016/02/04. https://doi.org/10.11 82/blood-2015-08-665505. 
9. Akhtar S, Elhassan TA, Edesa W, Rauf MS, Zahir MN, Maghfoor I. High-dose chemotherapy and autologous stem cell transplantation for relapsed or refractory nodular lymphocyte predominant Hodgkin lymphoma. Ann Hematol. 2016;95(1):49-54. https://doi.org/10.1007/s00277-015-2527-4.

10. Akhtar S, Montoto S, Boumendil A, Finel H, Masszi T, Jindra P, et al. High dose chemotherapy and autologous stem cell transplantation in nodular lymphocyte-predominant Hodgkin lymphoma: A retrospective study by the European society for blood and marrow transplantation-lymphoma working party. Am J Hematol. 2018;93(1):40-6. e-pub ahead of print 2017/10/04. https://doi.org/10.1002/ajh.24927.

11. Bierman P, Naushad H, Loberiza F, Bociek RG, Vose JM, Armitage JO, et al. High-dose chemotherapy followed by autologous hematopoietic stem cell transplantation (ahsct) for lymphocyte predominant hodgkin's disease. Blood. 2006;108:3061.

12. Karuturi M, Hosing C, Fanale M, Medeiros LJ, Alousi AM, de Lima MJ, et al. High-dose chemotherapy and autologous stem cell transplantation for nodular lymphocyte-predominant Hodgkin lymphoma. Biol Blood Marrow Transplant. 2013;19(6):991-4. e-pub ahead of print 2013/03/20. https://doi. org/10.1016/j.bbmt.2013.03.008

13. Eichenauer DA, Fuchs M, Pluetschow A, Klimm B, Halbsguth T, Boll B, et al. Phase 2 study of rituximab in newly diagnosed stage IA nodular lymphocyte-predominant Hodgkin lymphoma: a report from the German Hodgkin Study Group. Blood. 2011;118(16):4363-5. e-pub ahead of print 2011/08/11. https://doi.org/10.1182/blood-2011-06-361055.

14. Advani RH, Horning SJ, Hoppe RT, Daadi S, Allen J, Natkunam Y, et al. Mature results of a phase II study of rituximab therapy for nodular lymphocyte-predominant Hodgkin lymphoma. J Clin Oncol. 2014;32(9):9128. e-pub ahead of print 2014/02/12. https://doi.org/10.1200/jco.2013.53.2069.

15. Cheson BD, Horning SJ, Coiffier B, Shipp MA, Fisher RI, Connors JM, et al. Report of an international workshop to standardize response criteria for non-Hodgkin's lymphomas. $\mathrm{NCl}$ sponsored international working group. J Clin Oncol. 1999;17(4):1244-53. https://doi.org/10.1200/JCO.1999.17.4.1244.

16. Cheson BD, Fisher RI, Barrington SF, Cavalli F, Schwartz LH, Zucca E, et al. Recommendations for initial evaluation, staging, and response assessment of Hodgkin and non-Hodgkin lymphoma: the Lugano classification. J Clin Oncol. 2014;32(27):3059-68. e-pub ahead of print 2014/08/13. https://doi. org/10.1200/jco.2013.54.8800.

17. Campo E, Swerdlow SH, Harris NL, Pileri S, Stein H, Jaffe ES. The 2008 WHO classification of lymphoid neoplasms and beyond: evolving concepts and practical applications. Blood 2011; 117(19): 5019-5032 e-pub ahead of print 2011/02/09; doi: https://doi.org/10.1182/blood-2011-01-293050

18. Nogova L, Reineke T, Brillant C, Sieniawski M, Rudiger T, Josting A, et al. Lymphocyte-predominant and classical Hodgkin's lymphoma: a comprehensive analysis from the German Hodgkin study group. J Clin Oncol. 2008;26(3):434-9. e-pub ahead of print 2007/12/19. https://doi.org/1 0.1200/jco.2007.11.8869.

19. Posthuma HLA, Zijlstra JM, Visser O, Lugtenburg PJ, Kersten MJ, Dinmohamed AG. Primary therapy and survival among patients with nodular lymphocyte-predominant Hodgkin lymphoma: a population-based analysis in the Netherlands, 1993-2016. Br J Haematol. 2019. e-pub ahead of print 2019/11/05;189:117-21. https://doi.org/10.1111/bjh.16290.

20. Diehl V, Sextro M, Franklin J, Hansmann ML, Harris N, Jaffe E, et al. Clinical presentation, course, and prognostic factors in lymphocyte-predominant Hodgkin's disease and lymphocyte-rich classical Hodgkin's disease: report from the European task force on lymphoma project on LymphocytePredominant Hodgkin's disease. J Clin Oncol. 1999;17(3):776-83. e-pub ahead of print 1999/03/10. https://doi.org/10.1200/jco.1999.17.3.776.

21. Wirth A, Yuen K, Barton M, Roos D, Gogna K, Pratt G, et al. Long-term outcome after radiotherapy alone for lymphocyte-predominant hodgkin lymphoma: a retrospective multicenter study of the australasian radiation oncology lymphoma group. Cancer. 2005;104(6):1221-9. e-pub ahead of print 2005/08/12. https://doi.org/10.1002/cncr.21303.

22. Chen RC, Chin MS, Ng AK, Feng Y, Neuberg D, Silver B, et al. Early-stage, lymphocyte-predominant Hodgkin's lymphoma: patient outcomes from a large, single-institution series with long follow-up. J Clin Oncol. 2010;28(1):13641. e-pub ahead of print 2009/11/26. https://doi.org/10.1200/jco.2009.24.0945.

23. Solanki AA, LeMieux MH, Chiu BC, Mahmood U, Hasan Y, Koshy M. Longterm outcomes in patients with early stage nodular lymphocytepredominant Hodgkin's lymphoma treated with radiotherapy. PloS One. 2013;8(9):e75336. e-pub ahead of print 2013/09/24. https://doi.org/10.1371/ journal.pone.0075336.
24. Eichenauer DA, Plutschow A, Fuchs M, von Tresckow B, Boll B, Behringer $K$, et al. Long-term course of patients with stage ia nodular lymphocytepredominant hodgkin lymphoma: a report from the german hodgkin study group. J Clin Oncol. 2015;33(26):2857-62. e-pub ahead of print 2015/08/05. https://doi.org/10.1200/jco.2014.60.4363.

25. Gerber NK, Atoria CL, Elkin EB, Yahalom J. Characteristics and outcomes of patients with nodular lymphocyte-predominant Hodgkin lymphoma versus those with classical Hodgkin lymphoma: a population-based analysis. Int J Radiat Oncol Biol Phys. 2015;92(1):76-83. e-pub ahead of print 2015/04/13. https://doi.org/10.1016/j.jijobp.2015.02.012.

26. Parikh RR, Grossbard ML, Harrison LB, Yahalom J. Early-stage nodular lymphocyte-predominant Hodgkin lymphoma: the impact of radiotherapy on overall survival. Leuk Lymphoma. 2016;57(2):320-7. e-pub ahead of print 2015/06/26. https://doi.org/10.3109/10428194.2015.1065978.

27. Molin D, Linderoth J, Wahlin BE. Nodular lymphocyte predominant Hodgkin lymphoma in Sweden between 2000 and 2014: an analysis of the Swedish Lymphoma Registry. Br J Haematol. 2017;177(3):449-56. e-pub ahead of print 2017/02/25. https://doi.org/10.1111/bjh.14567.

28. Shivarov $V$, Ivanova M. Nodular lymphocyte predominant Hodgkin lymphoma in USA between 2000 and 2014: an updated analysis based on the SEER data. Br J Haematol. 2018;182(5):727-30. e-pub ahead of print 2017/07/25. https://doi.org/10.1111/bjh.14861.

29. Alonso C, Dutta SW, Mitra N, Landsburg DJ, Zaorsky NG, Grover S, et al. Adult nodular lymphocyte-predominant Hodgkin lymphoma: treatment modality utilization and survival. Cancer Med. 2018;7(4):1118-26. e-pub ahead of print 2018/02/27. https://doi.org/10.1002/cam4.1383.

30. Rauf MS, Akhtar S, Maghfoor I. Changing trends of adult lymphoma in the Kingdom of Saudi Arabia - comparison of data sources. Asian Pac J Cancer Prev. 2015;16(5):2069-72. e-pub ahead of print 2015/03/17. https://doi.org/1 0.7314/apjcp.2015.16.5.2069.

31. Bailey CE, Jung F, Addicks B, Esan OA, Kellermeyer B. Nodular lymphocytepredominant hodgkin lymphoma in progressive transformation of germinal centers. Case Rep Otolaryngol. 2017;2017:5982168. e-pub ahead of print 2018/01/20. https://doi.org/10.1155/2017/5982168.

32. Hansmann ML, Fellbaum C, Hui PK, Moubayed P. Progressive transformation of germinal centers with and without association to Hodgkin's disease. Am Journal Clin Pathol. 1990;93(2):219-26. e-pub ahead of print 1990/02/01. https://doi.org/10.1093/ajcp/93.2.219.

33. Hicks J, Flaitz C. Progressive transformation of germinal centers: review of histopathologic and clinical features. Int J Pediatr Otorhinolaryngol. 2002; 65(3):195-202. e-pub ahead of print 2002/09/21. https://doi.org/10.1016/s01 65-5876(02)00176-3.

34. Burns BF, Colby TV, Dorfman RF. Differential diagnostic features of nodular L \& H Hodgkin's disease, including progressive transformation of germinal centers. Am J Surg Pathol. 1984;8(4):253-61. e-pub ahead of print 1984/04/ 01. https://doi.org/10.1097/00000478-198404000-00002.

\section{Publisher's Note}

Springer Nature remains neutral with regard to jurisdictional claims in published maps and institutional affiliations.
Ready to submit your research? Choose BMC and benefit from:
- fast, convenient online submission
- thorough peer review by experienced researchers in your field
- rapid publication on acceptance
- support for research data, including large and complex data types
- gold Open Access which fosters wider collaboration and increased citations
- maximum visibility for your research: over $100 \mathrm{M}$ website views per year
At BMC, research is always in progress.
Learn more biomedcentral.com/submissions 